UDC 338:614.2+351

DOI: https://doi.org/10.32782/2224-6282/164-27

\author{
Matviyiv Vasyl \\ Lutsk National Technical University
}

Матвї̈в В. В.

здобувач наукового ступеня доктора філософії, Луцький національний технічний університет

\title{
ANALYSIS OF PROVISION OF MEDICAL SERVICES TO THE POPULATION BY PRIMARY MEDICAL CARE DOCTORS IN THE CONDITIONS OF HEALTH SYSTEM REFORM: REGIONAL LEVEL
}

An important component of the development of the domestic medical system has been the reform of the primary level of health care facilities. The impetus for this was the adoption of the main draft laws, which significantly changed the distribution of funds for the financing of the medical sector in Ukraine. The article describes the percentage of the population that chose their primary care physician, analyzes the distribution of declarations by the number and structure of primary medical care providers who have concluded an agreement with the National Health Service of Ukraine in Ukraine and the Carpathian region. It was cleared up that both in Ukraine and in its regions the population had the right to choose primary care physicians among such specialties as family doctors, therapists and pediatricians, where as a result of compiling declarations the largest population in Ukraine chose family doctors in Transcarpathian, Lviv and Chernivtsi regionss, and the share of family doctors in these regions significantly exceeds the Ukrainian average in the country. It has been determined that an important factor is public awareness about the importance and necessity of electronic declarations. The study concludes that this, in its turn, has provided the population with a free choice of a therapist in urban areas or a family general practitioner in rural areas. It has been investigated that the population has a free choice to sign declarations with primary care doctors, and this allows each citizen to choose a doctor at his discretion, who, in turn, having the opportunity to provide services and receive a slightly higher fee according to the coefficients approved by the National Health Service of Ukraine. It has been concluded that patients have the opportunity to receive medical services from primary care physicians, as a result of which they can receive qualified medical care. Under conditions when in patients'opinions medical care or services are not provided at the appropriate level, they can change doctors and automatically sign a declaration with another doctor.

Keywords: medical services, health care, medical care, family doctor, therapist, primary medical care.

\section{АНАЛІЗ НАДАННЯ МЕДИЧНИХ ПОСЛУГ НАСЕЛЕННЮ ЛІКАРЯМИ ПЕРВИННОЇ МЕДИЧНОЇ ДОПОМОГИ В УМОВАХ РЕФОРМУВАННЯ СИСТЕМИ ОХОРОНИ ЗДОРОВ'Я: РЕГІОНАЛЬНИЙ РІВЕНЬ}

Важливою складовою розвитку вітчизняної медичної системи стало реформування первинної ланки закладів охорони здоров'я. Поштовхом для изього стали основні законодавчі акти, які суттєво змінили розподіл коштів щодо фінансування медичної галузі в Україні. В статті охарактеризовано відсоток населення, яке обрало свого лікаря первинної ланки, проаналізовано розподіл декларачій за кількістю та структурою надавачів ПМД, які уклали договір з НСЗУ по Україні та областях Карпатського регіону. Окреслено розподіл підписаних декларацій населення відповідно до вікових груп по Украӥні та в Карпатському регіоні. 3 'ясовано, щяо як в Україні, так $і$ в регіонах населення мало право вибору лікарів первинної медичної допомоги серед таких спеціальностей як сімейні лікарі, терапевти та педіатри. В результаті укладання декларацій найбільше населення в Украйні обрало за спеціальностями сімейних лікарів в 3 акарпатській області, Львівській та Чернівецькій областях, й частка сімейних лікарів у цих областях значно перевищує середньостатистичний показник по країні. Визначено, що важливим фактором є інформованість суспільства про важливість та необхідність оформлення електронних декларацій. 3 дослідження узагальнено, що ие в свою чергу забезпечило вільний вибір населення лікаря терапевта у міських зонах чи сімейного лікаря загальної практики у сільській місиевості. Досліджено, щь населення має вільний вибір щьодо підписання декларачій з лікарями ПМД, і ще дає змогу кожному громадянину вибрати на власний розсуд лікаря, який, в свою чергу, маючи можливість надавати послуги $i$ отримувати у декілька разів більшу винагороду згідно коефіиієнтів, які затвердили в НСЗУ. Підсумовано, щзо пацієнти мають можливість отримувати медичні послуги в лікарів первинної ланки, в результаті чого вони можуть отримувати кваліфіковану медичну допомогу. При умовах, коли, на думку пацієнтів, медична допомога чи послуги не надаються на відповідному рівні, вони можуть змінити лікаря й автоматично підписати декларацію у іншого лікаря.

Ключові слова: медичні послуги, охорона здоров'я, медична допомога, сімейний лікар, терапевт, первинна медична допомога.

Setting of the problem. In modern conditions, the completion of the reform of the secondary and tertiary levels of the medical sphere is a strategically important factor in the further development of the medical sphere. The adoption of a number of bills at the legislative level concerning the reform of the medical sector has changed the approach to financing the medical sector, according to which funding is provided for each patient, i.e. according to the well-known the National Health Service of Ukraine formula of "Money follows the patient".

An important step in the process of reforming the health care system was the signing of electronic declarations 
between the population and primary medical care physicians, during which the population was given the opportunity to directly choose their doctor. All this was supposed to help improve the quality of services provided to patients and create a transparent environment for health care facilities.

Analysis of recent researches and publications. The problems of reforming the medical health care system are reflected in the publications of scientists, including V. Pashkova , V. Kostyuk, V. Lekhan, and a number of other researchers.

At the same time, the scientific literature requires a more thorough analysis of the provision of free medical services by health care institutions that have signed an agreement with the National Health Service of Ukraine.

The aim of the work is to analyze the provision of medical services to the population by primary care physicians in the context of health care reform.

Presenting of the main material. The reform of the health care sector foresaw gradual reform of all parts of the medical system, which would ensure equal access of the population of Ukraine to medical services, especially to urgent ones.

An important starting point was April 1, 2018 when the first wave of reforms began and the population was able to sign electronic declarations (agreements) with family doctors, therapists and pediatricians. Thus, by signing an electronic declaration with a doctor, patients were given the opportunity to receive certain free medical services, which were included in the packages of free medical guarantees.

As of January 1, 2020, the share of the population in the regions of Ukraine that has chosen a primary care physician is shown in Table 1.

Table 1

Percentage of the population that has chosen their primary care physicians

\begin{tabular}{|l|c|}
\hline \multicolumn{1}{|c|}{ Regions } & Percentage \\
\hline Cherkasy & 77 \\
\hline Chernivtsi & 75 \\
\hline Chernihiv & 79 \\
\hline Dnipropetrovsk & 76 \\
\hline Donetsk & 32 \\
\hline Ivano-Frankivsk & 78 \\
\hline Kharkiv & 77 \\
\hline Kherson & 74 \\
\hline Khmelnytsky & 81 \\
\hline Kirovograd & \\
\hline Kyiv & \\
\hline Luhansk & 22 \\
\hline Lviv & 81 \\
\hline Mykolayiv & 70 \\
\hline Odessa & 66 \\
\hline Poltava & 80 \\
\hline Rivne & 80 \\
\hline Sumy & 81 \\
\hline Ternopil & 78 \\
\hline The city of Kyiv & 66 \\
\hline Transcarpathian & 74 \\
\hline Vinnytsia & 83 \\
\hline Volyn & 81 \\
\hline Zaporizhzha & 76 \\
\hline Zhytomyr & 80 \\
\hline Source: [4] &
\end{tabular}

Thus, according to the National Health Service of Ukraine, the smallest share of signed declarations with doctors of primary health care facilities is observed among the population living in the temporarily occupied territories of Ukraine in Donetsk and Luhansk regions. The percentage of the signed declarations in Luhansk and Donetsk regions fluctuates between 22 and 32 percent, which is the lowest in Ukraine, respectively.

One of the main trends in conclusion of declarations is that in each of the twenty-two regions of Ukraine, except for the temporarily occupied territories where Joint Force Operation is conducted, the percentage of the population who signed the declaration and chose a doctor for a year and a half exceeded 60 per cent. Thus, the leaders among the regions of Ukraine in which the highest share of the population chose a family doctor are Vinnytsia region (83\%), Kyiv region (83 per cent), Volyn region (81 per cent) and Lviv region (81 per cent).

These results indicate that the population in these regions of Ukraine was sufficiently informed about the importance and necessity of electronic declarations, which will ensure the patient's right to choose a physician or family doctor for family members regardless of age in rural areas and the free choice of a pediatrician in urban areas if there are under age children under 18 years of age in the family. The above mentioned physicians are obliged to provide each of the patients with urgent medical care and services and, if necessary, to send them to narrow-purpose medical specialists.

More than a year and a half of reforming the primary health care sector gives us an understanding that the population is gradually learning about all the conditions for free medical services, as well as about medical institutions that have signed agreements with the National Health Service of Ukraine for receiving targeted funding for specific services in the future.

Starting from 2018, the number of medical institutions that sign agreements with the National Health Service of Ukraine for provision of medical services to the population is gradually increasing (Table 2).

Among the medical institutions that have signed agreements with the National Health Service of Ukraine, communal institutions predominate, the share of which averages 71.6 percent in the country; in terms of the Carpathian region, most communally-owned medical institutions signed an agreement with the National Health Service of Ukraine in Chernivtsi region (90.2 per cent), and the least in Transcarpathian region (43.7 per cent). In our opinion, there is a positive trend in the market share of private medical institutions that are ready to provide medical services to patients and have signed an agreement with the National Health Service of Ukraine. We believe that their share will grow both in Ukraine in general and in the Carpathian region in particular.

The evidence of the above trend is, in particular, the fact that in Transcarpathian and Ivano-Frankivsk regions this figure exceeds the average in Ukraine, and is 16.7 and 12.5 per cent, respectively. This is due to the fact that privately owned medical institutions are gradually increasing their market share, and patients accordingly choose their doctor from among the medical staff of private medical institutions.

Some doctors who have experience and long-term medical practice open their own offices, and having the 
Table 2

Distribution of declarations by the number and structure of primary medical care providers who have concluded an agreement with the National Health Service of Ukraine in Ukraine and the regions of the Carpathian region in 2019

\begin{tabular}{|c|c|c|c|c|c|c|c|}
\hline & \multirow{2}{*}{$\begin{array}{c}\text { Number } \\
\text { of medical } \\
\text { service } \\
\text { providers, } \\
\text { units }\end{array}$} & \multicolumn{2}{|c|}{ Communal } & \multicolumn{2}{|c|}{ Private (without FOP) } & \multicolumn{2}{|c|}{ FOP } \\
\hline & & $\begin{array}{l}\text { Number of } \\
\text { medical service } \\
\text { providers, units }\end{array}$ & $\begin{array}{c}\text { Structure, } \\
\text { per cent }\end{array}$ & $\begin{array}{c}\text { Number of } \\
\text { health care } \\
\text { provider, units }\end{array}$ & $\begin{array}{l}\text { Structure, } \\
\text { per cent }\end{array}$ & $\begin{array}{l}\text { Number of } \\
\text { health care } \\
\text { providers, } \\
\text { units }\end{array}$ & $\begin{array}{c}\text { Structure, } \\
\text { per cent }\end{array}$ \\
\hline Ukraine & 1466 & 1050 & 71,6 & 168 & 11,5 & 248 & 16,9 \\
\hline $\begin{array}{l}\text { Transcar-pathian } \\
\text { region }\end{array}$ & 48 & 21 & 43,7 & 8 & 16,7 & 19 & 39,6 \\
\hline $\begin{array}{l}\text { Ivano-Frankivsk } \\
\text { region }\end{array}$ & 72 & 47 & 65,3 & 9 & 12,5 & 16 & 22,2 \\
\hline Lviv region & 120 & 90 & 75,0 & 7 & 5,8 & 23 & 19,2 \\
\hline Chernivtsi region & 41 & 37 & 90,2 & 1 & 2,5 & 3 & 7,3 \\
\hline
\end{tabular}

Source: [4]

opportunity to sign a contract with the National Health Service of Ukraine, have the right to make electronic declarations with patients about the provision of medical services and receive budget funding for each patient.

As a result, we observe a situation in which doctorsindividual entrepreneurs after obtaining a license for carrying out medical activities, successfully recruit patients, especially among those who have previously sought medical help. Patients who, having a positive experience of treatment with these doctors in the past or thanks to advices from their acquaintances, now officially conclude electronic declarations with them.

Evidence of the growing trust of patients in doctorsindividual entrepreneurs is that as of 01.01.2020 there were 248 doctors-individual entrepreneurs in Ukraine who concluded agreements with the National Health Service of Ukraine, and in the structure of all health care providers in Ukraine their share comprise 16.9 per cent. Thus, in the Carpathian region, in Chernivtsi region in particular, their share was 7.3 per cent, which is slightly lower than the average in Ukraine, and in other regions of the Carpathian region - Transcarpathian, Ivano-Frankivsk and Lviv - the share of doctors-individual entrepreneurs is 39, 6, 22.2 and 19.2 percent respectively.

Thus, the population has a free choice to sign declarations with primary care physicians, and this allows each citizen to choose a physician at their own discretion who, in turn, is interested in forming a patient base for which a physician will receive budget funding.

The distribution of signed declarations of the population with primary care physicians by age groups in Ukraine and in the Carpathian region, in particular, is presented by us in Table 3.

Thus, in the structure of the age category of the population, the largest percentage of people who have signed a declaration with a doctor is between 40 and 64 years old.

According to the report of the National Health Service Fund, the share of the population of this age group in Ukraine is 34.2 percent of the total number of signed declarations, in Lviv region - 32.9 per cent, in IvanoFrankivsk region -32.5 per cent [4]. This shows that this category of the population, already having chronic diseases and taking care of their own health in advance, understands the importance of choosing a doctor who can consult in case of need.

The second age group of the population aged 18 to 39 , who have signed a declaration with a family doctor or a therapist, is the most socially active part of the society according to age category, which is mostly responsible for maintaining their own health and the health of others and has an understanding and their own vision of the situation, i.e. their own worldview, which the National Health Insurance Fund definitely refers them to the second age group in terms of the number of signed electronic declarations with a primary care doctor. Accordingly, the share of the population of this age category among the total population who concluded declarations with a doctor is 25.6 per cent in Transcarpathian region, 28.6 per cent in Lviv region, 27.7 per cent in Ivano-Frankivsk region, 27.6 per cent in Chernivtsi region.

The structure of declarations with pediatricians compiled by parents on behalf of the youngest patients, who belong to the age category from 0 to 5 years, is as follows: in Transcarpathian region -8.4 per cent, in Chernivtsi region - 8.0 per cent, in Ivano-Frankivsk and Lviv regions -7.5 and 7.2 per cent respectively. Regarding the age category of older children and juveniles aged 6 to 7 years, the largest share of declarations is in Transcarpathian and Chernivtsi regions -18.2 and 16.6 per

Table 3

Distribution of declarations by age groups of the population in Ukraine and regions of the Carpathian region in 2019

\begin{tabular}{|l|c|c|c|c|c|}
\hline & \multicolumn{5}{|c|}{ Age group of the population } \\
\hline & $0-5$ & $6-17$ & $18-39$ & $40-64$ & $65+$ \\
\hline Ukraine & 6,9 & 15,1 & 25,6 & 34,2 & 18,2 \\
\hline Transcarpathian region & 8,4 & 18,2 & 28,6 & 31,2 & 13,5 \\
\hline Ivano-Frankivsk region & 7,5 & 16,5 & 27,7 & 32,5 & 15,8 \\
\hline Lviv region & 7,2 & 15,3 & 28,6 & 32,9 & 15,9 \\
\hline Chernivtsi region & 8,0 & 16,6 & 27,6 & 31,4 & 16,4 \\
\hline
\end{tabular}

Source: [4] 
cent, respectively, and in Ivano-Frankivsk and Lviv 16.56 per cent and 15,36 per cent respectively, which exceeds the average in Ukraine - 15.1 per cent.

As for the elderly people, this age category of the population ranks third among the five age categories in the percentage of all declarations for primary health care services. This is due to the fact that despite the constant need for medical services in connection with the presence of chronic diseases, this category of people was in no hurry to conclude declarations due to inability to use cellular communication required to read text messages during registration, often because of no outside help from relatives who would help to get to a certain medical institution in an urban area or to an outpatient clinic in a rural area. These facts clearly show that only in the presence of the above favorable factors, people of retirement age would be happy to compile a declaration with the appropriate doctor.

Regarding the choice of doctors by specialties, it is important to note that among the signed declarations the population of Ukraine was able to choose doctors from three main specialties: family doctor, therapist and pediatrician (Table 4).

Distribution of declarations
$\begin{aligned} & \text { of the population by doctors' specialties in Ukraine } \\
& \text { and regions of the Carpathian region in 2019 }\end{aligned}$
\begin{tabular}{|l|c|c|c|}
\hline \multirow{2}{*}{} & \multicolumn{3}{|c|}{ Specialties of doctors } \\
\cline { 2 - 4 } & $\begin{array}{c}\text { Family } \\
\text { doctor }\end{array}$ & Therapeutist & Pediatrician \\
\hline Ukraine & 74 & 15 & 11 \\
\hline $\begin{array}{l}\text { Transcarpathian } \\
\text { region }\end{array}$ & 94 & $4 \%$ & $2 \%$ \\
\hline $\begin{array}{l}\text { Ivano-Frankivsk } \\
\text { region }\end{array}$ & 59 & 29 & 12 \\
\hline Lviv region & 79 & 13 & 8 \\
\hline Chernivtsi region & 78 & 16 & 6 \\
\hline
\end{tabular}

Source: [4]

Thus, among the concluded declarations, the largest share of the population concluded declarations on specialties of doctors, the most concluded declarations with family doctors, where in Ukraine this figure is 74 per cent, physicians - 15 per cent and pediatricians -11 per cent.

The situation is somewhat different in four regions of the Carpathian region, where among primary care physicians who render assistance in three regions, the level of signing declarations with a family doctor is much higher than the average in Ukraine in Zakarpattia, Lviv and Chernivtsi regions. The exception is Ivano-Frankivsk region, where the distribution of signed declarations with primary care physicians is optimally distributed among family physicians, therapists and pediatricians.

Thus, there is still a small proportion of the population of Ukraine who have not compiled a declaration with a family doctor or therapist, in particular due to various circumstances (including temporary residence outside Ukraine) and if necessary they can always choose their doctor to provide medical services and necessary consultations in the future for patients.

Conclusions and prospects for further research in this direction Summarizing this study on the concluded declarations of the population of Ukraine and the Carpathian region, we can draw the following conclusions:

1. The introduction of health care reform in 2018, despite all the negative and positive aspects, gave impetus to the population to choose doctors according to their own criteria and preferences, which they can, and in fact they should trust them, to avoid complications of many diseases in the future.

2. An important factor was that private medical institutions in Ukraine and private doctors were given the opportunity to enter into agreements with the National Health Service Fund and to receive budget funds for each patient with whom they signed a declaration. This has enabled many patients to use the services of private health care facilities and receive qualified medical care and quality services from them.

3. Taking advantage of the opportunity to receive medical services from primary care physicians to provide the necessary medical services, the population was able to receive qualified medical care, and in the absence of such care - the opportunity to change doctors to another more qualified, without notifying and asking for consent.

\section{References:}

1. Avramenko N.V. (2010) Derzhavne upravlinnja systemoju okhorony zdorov'ja na reghionaljnomu rivni: suchasnyj stan, shljakhy vdoskonalennja [Public administration of the health care system at the regional level: current status, ways to improve]. Zaporizhzhja: KPU, 196 p.

2. Gholovni naprjamky majbutnjoji reformy systemy okhorony zdorov'ja Ukrajiny [The main directions of the future reform of the health care system of Ukraine]. Centr medychnogho ta reproduktyvnogho prava. Available at: http://www.medlawcenter.com.ua/ua/ news/958.html (accessed 27 November 2020).

3. Derzhavne upravlinnja reformuvannjam systemy okhorony zdorov'ja v Ukrajini [Public administration of health care reform in Ukraine]: navch.-nauk. vyd. / avt. kol.: M.M. Bilynsjka, Ja.F. Radysh, I.V. Rozhkova ta in. ; za zagh. red. prof. M.M. Bilynsjkoji. Kyjiv-Ljviv : NADU, 2012. 240 p.

4. Zvit Nacionaljnoji sluzhby zdorov'ja Ukrajiny 2019 [Report of the National Health Service of Ukraine 2019]. Available at: https://nszu.gov.ua/storage/files/zvit-2019_1586443884.pdf?1611529524 (accessed 27 November 2020).

5. Kovtanjuk P. Modelj chesnoji medycyny. Jak proponujutj reformuvaty finansuvannja okhorony zdorov'ja [Model of honest medicine. How to reform health care financing]. Ukrajinsjka pravda. Zhyttja. Available at: http://life.pravda.com.ua/ columns/2016/03/15/209406 (accessed 27 November 2020).

6. Kolomijecj O.O. (2018) Systema okhorony zdorov'ja v Ukrajini: nedoliky orghanizaciji ta ryzyky reformuvannja [The health care system in Ukraine: shortcomings of the organization and risks of reform]. Ekonomichnyj visnyk NTUU «KPI», no. 15. Available at: https://ela.kpi.ua/bitstream/123456789/26372/1/EV2018_18-27.pdf (accessed 27 November 2020).

7. Koncepcija reformy finansuvannja systemy okhorony zdorov'ja Ukrajiny pidghotovlena robochoju ghrupoju z pytanj reformy finansuvannja okhorony zdorov'ja pry MOZ Ukrajiny. Ljutyj 2016 [The concept of health care financing reform in Ukraine was prepared by the working group on health care financing reform at the Ministry of Health of Ukraine. February 2016]. Available at: http://uoz.cn.ua/reforma022016.pdf (accessed 27 November 2020). 
8. Kostjuk V.S. Reformuvannja okhorony zdorov'ja v Ukrajini v umovakh jevropejsjkoji orijentaciji [Health care reform in Ukraine in the context of European orientation]. Naukovyj visnyk Mizhnarodnogho ghumanitarnogho universytetu. Available at: http://www.vestnik-econom.mgu.od.ua/journal/2017/24-2-2017/11.pdf (accessed 27 November 2020).

9. Lekhan V.M., Krjachkova L.V., Zajarsjkyj M.I. (2018) Analiz reform okhorony zdorov'ja v Ukrajini: vid zdobuttja nezalezhnosti do suchasnosti [Analysis of health care reforms in Ukraine: from independence to the present]. UKRAJiNA. ZDOROV'Ja NACIJi, no. 4. Available at: http://www.irbis-nbuv.gov.ua/cgi-bin/irbis_nbuv/cgiirbis_64.exe?C21COM=2\&I21DBN=UJRN\&P21DBN=UJR N\&IMAGE_FILE_DOWNLOAD=1\&Image_file_name=PDF/Uzn_2018_4_ 3 .pdf (accessed 27 November 2020).

10. Mizhnarodnyj dosvid reformuvannja systemy okhorony zdorov'ja(dosvid krajin Jevropejsjkogho Sojuzu). Informacijna dovidka, pidghotovlena Jevropejsjkym informacijno-doslidnycjkym centrom na zapyt narodnogho deputata Ukrajiny [International experience in health care reform (experience of the European Union): Information reference prepared by the European Information and Research Center at the request of the People's Deputy of Ukraine]. Available at: http://euinfocenter.rada.gov.ua/uploads/documents/29185.pdf (accessed 27 November 2020).

11. Muzyka I.S. (2016) Reforma okhorony zdorov'ja: problemy, analiz, naprjamy realizaciji (na prykladi Karpatsjkogho reghionu Ukrajiny) [Health care reform: problems, analysis, areas of implementation (on the example of the Carpathian region of Ukraine)]. Socialjno-ekonomichni problemy suchasnogho periodu Ukrajiny. Vypusk 2 (118), pp. 38-42. Available at: http://nbuv.gov.ua/UJRN/ sepspu_2016_2_10 (accessed 27 November 2020).

12. Muzyka I.S., Voznjak Gh.V. (2016) Systema okhorony zdorov'ja v umovakh instytucijnykh zmin v Ukrajini: finansovi aspekty [The health care system in the context of institutional change in Ukraine: financial aspects]. Svit finansiv, no. 1, 99-108.

13. Pashkov V.M. (2017) Pravove zabezpechennja reformuvannja sfery okhorony zdorov'ja [Legal support for health care reform]. Medychne pravo, no. 2 (118) III-IV. Available at: https://www.umj.com.ua/article/107586/pravove-zabezpechennya-reformuvannyasferi-ohoroni-zdorov-ya (accessed 27 November 2020).

14. Popchenko T. Shhodo priorytetnykh naprjamiv vdoskonalennja vitchyznjanoji sfery okhorony zdorov'ja. Analitychna zapyska [Regarding the priority areas for improving the domestic healthcare sector. Analytical note]. Nacionaljnyj instytut strateghichnykh doslidzhenj. Available at: http://old2.niss.gov.ua/articles/480 (accessed 27 November 2020).

15. Reforma systemy okhorony zdorov'ja: $\mathrm{v}$ ochikuvanni pershykh rezuljtativ [Health care reform: waiting for the first results]. Available at: http://library.fes.de/pdf-files/bueros/ukraine/14938.pdf (accessed 27 November 2020).

16. Rozvytok derzhavnogho upravlinnja reformuvannjam okhorony zdorov'ja v Ukrajini na reghionaljnomu rivni: stan, problemy, perspektyvy [Development of public administration of health care reform in Ukraine at the regional level: status, problems, prospects]: metod. rek. / avt. kol. : T. P. Avramenko, L. I. Zhalilo, O. I. Martynjuk ta in. Kyiv: NADU, 2013. 48 p. Available at: http://academy.gov.ua/ NMKD/library_nadu/Navch_Posybniky/668f8f42-b871-4774-8229-565fa1c6ec80.pdf (accessed 27 November 2020).

\section{Список використаних джерел:}

1. Авраменко Н.В. Державне управління системою охорони здоров'я на регіональному рівні: сучасний стан, шляхи вдосконалення. Запоріжжя : КПУ, 2010.196 с.

2. Головні напрямки майбутньої реформи системи охорони здоров'я України. Центр медичного та репродуктивного права. URL: http://www.medlawcenter.com.ua/ua/news/958.html (дата звернення: 27.11.2020).

3. Державне управління реформуванням системи охорони здоров'я в Україні : навч.-наук. вид. / авт. кол.: М.М. Білинська, Я.Ф. Радиш, І.В. Рожкова та ін. ; за заг. ред. проф. М.М. Білинської. Київ-Львів: НАДУ, 2012. 240 с.

4. Звіт Національної служби здоров'я України 2019. URL: https://nszu.gov.ua/storage/files/zvit-2019_1586443884.pdf?1 611529524 (дата звернення: 27.11.2020).

5. Ковтанюк П. Модель чесної медицини. Як пропонують реформувати фінансування охорони здоров'я. Українська правда. Життя. URL: http://life.pravda.com.ua/columns/2016/03/15/209406 (дата звернення: 27.11.2020).

6. Коломієць О.О. Система охорони здоров’я в Україні: недоліки організації та ризики реформування Економічний вісник НТУУ «КПI». 2018. № 15. URL: https://ela.kpi.ua/bitstream/123456789/26372/1/EV2018_18-27.pdf (дата звернення: 27.11.2020).

7. Концепція реформи фінансування системи охорони здоров'я України підготовлена робочою групою 3 питань реформи фінансування охорони здоров'я при MO3 України. Лютий 2016. URL: http://uoz.cn.ua/reforma0216.pdf (дата звернення: 27.11.2020).

8. Костюк В.С. Реформування охорони здоров'я в Україні в умовах європейської орієнтації. Науковий вісник Міжнародного гуманітарного університету. URL: http://www.vestnik-econom.mgu.od.ua/2017/24-2-2017/11.pdf (дата 3вернення: 27.11.2020).

9. Лехан В.М., Крячкова Л.В., Заярський М.I. наліз реформ охорони здоров’я в Україні: від здобуття незалежності до сучасності. Україна. Здоров'я наиї̈. 2018. № 4. URL: http://www.irbis-nbuv.gov.ua/cgi-bin/irbis_nbuv/cgiirbis_64.exe?C21COM=2\&I21 DBN=UJRN\&P21DBNIMAGE_FILE_DOWNLOAD=1\&Image_file_name=PDF/Uzn_2018_4_3.pdf (дата звернення: 27.11.2020).

10. Міжнародний досвід реформування системи охорони здоров'я(досвід країн Європейського Союзу) Інформаційна довідка, підготовлена Європейським інформаційно-дослідницьким центром на запит народного депутата України. URL: http://euinfocenter.rada.gov.ua/uploads/documents/29185.pdf (дата звернення: 27.11.2020).

11. Музика I.C. Реформа охорони здоров'я: проблеми, аналіз, напрями реалізації (на прикладі Карпатського регіону України). Соціально-економічні проблеми сучасного періоду України. 2016. Випуск 2 (118). C. 38-42. URL: http://nbuv.gov.ua/UJRN/ sepspu_2016_2_10 (дата звернення: 27.11.2020).

12. Музика І.С., Возняк Г.В. Система охорони здоров'я в умовах інституційних змін в Україні: фінансові аспекти. Світ фінансів. 2016. № 1. С. 99-108.

13. Пашков В.М. Правове забезпечення реформування сфери охорони здоров'я. Медичне право. 2017. № 2 (118) III-IV. URL: https://www.umj.com.ua/article/107586/pravove-zabezpechennya-reformuvannya-sferi-ohoroni-zdorov-уа (дата звернення: 27.11.2020).

14. Попченко Т. Щодо пріоритетних напрямів вдосконалення вітчизняної сфери охорони здоров’я. Аналітична записка. Національний інститут стратегічних досліджень. URL: http://old2.niss.gov.ua/articles/480 (дата звернення: 27.11.2020).

15. Реформа системи охорони здоров'я: в очікуванні перших результатів. URL: http://library.fes.de/pdf-files/bueros/ ukraine/14938.pdf (дата звернення: 27.11.2020).

16. Розвиток державного управління реформуванням охорони здоров'я в Україні на регіональному рівні: стан, проблеми, перспективи : метод. рек. / авт. кол. : Т.П. Авраменко, Л.I. Жаліло, О.I. Мартинюк та ін. Київ : НAДУ, 2013. 48 с. URL: http://academy.gov.ua/NMKD/library_nadu/Navch_Posybniky/668f871-4774-8229-565fa1c6ec80.pdf (дата звернення: 27.11.2020). 